\title{
Selected bacterial strains enhance phosphorus availability from biochar-based rock phosphate fertilizer
}

\author{
Aline de Amaral Leite(D), Arnon Afonso de Souza Cardoso (D, Rafael de Almeida Leite(D), \\ Silvia Maria de Oliveira-Longatti(D, José Ferreira Lustosa Filho(D, Fatima Maria de Souza Moreira(1) and \\ Leônidas Carrijo Azevedo Melo* (1)
}

\begin{abstract}
Purpose: The co-pyrolysis of biomass and soluble phosphates generates biochar-based phosphate fertilizers (BBF), which may enhance phosphorus (P) input in soil and P uptake by plants. Conversely, pyrolysis of biomass impregnated with rock phosphate results in low $\mathrm{P}$ solubility and may not supplement plant requirement in short term. However, bacterial strains promoting rock phosphate solubilization increases $\mathrm{P}$ use efficiency and can be applied to BBFs.

Methods: An in vitro assay was conducted to investigate the solubilization profile of five bacterial strains (Pseudomonas sp.-UFPI-B5-8A, Burkholderia fungorum-UFLA 04-155, Acinetobacter sp.-UFLA 03-09, Paenebacillus kribbensis_-UFLA 03-10, and Paenibacillus sp.-UFLA 03-116) isolated from common bean and cowpea nodules in a rock phosphate BBF. Additionally, a pot trial was carried out aiming to investigate the influence on maize growth by inoculation of three selected strains under a rock phosphate BBF fertilization.

Results: Inoculations with UFPI B5-8A, UFLA 04-155, and UFLA 03-09 were efficient in solubilizing P in vitro, being closely associated with $\mathrm{pH}$ decrease, likely due to the release of organic acids. As for the pot trial, the dose of 400 $\mathrm{mg} \mathrm{kg}^{-1}$ of $\mathrm{P}$ in the BBF using UFPI B5-8A significantly increased maize shoot dry matter. All strains significantly enhanced $P$ availability in the soil.
\end{abstract}

Conclusions: Bacterial inoculation in biochar-based rock phosphate aiming to improve its fertilizer value is an inexpensive and sustainable strategy to improve maize growth and enhance available $P$ in soil and should be further explored.

Keywords: Bacterial inoculation, Bayóvar phosphate rock, Phosphate solubilization, Zea mays

\section{Introduction}

Phosphorus (P) is a major growth-limiting nutrient for food production. The main $P$ sources of phosphate fertilizers are phosphate rocks, which are finite and scarce and cannot be replaced (Scholz et al. 2013). Phosphorus has a complex dynamic in soil, mainly in tropical soils due to acidity and high levels of $\mathrm{Fe}$ and $\mathrm{Al}$ oxides (Abdala et al. 2015). This acidic and oxidic mineral composition results in low available $\mathrm{P}$ fraction for plant uptake and low efficiency of phosphate fertilizers, which

\footnotetext{
* Correspondence: leonidas.melo@ufla.br

Soil Science Dept., Federal University of Lavras/UFLA, Lavras, MG 37200-000, Brazil
}

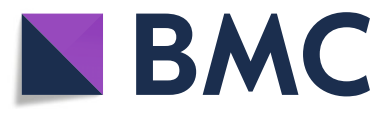

(อ) The Author(s). 2020 Open Access This article is distributed under the terms of the Creative Commons Attribution 4.0 International License (http://creativecommons.org/licenses/by/4.0/), which permits unrestricted use, distribution, and reproduction in any medium, provided you give appropriate credit to the original author(s) and the source, provide a link to the Creative Commons license, and indicate if changes were made. tion rates to achieve profitable agricultural yields. Acidified phosphate fertilizers, characterized with high watersoluble P contents, are the main P sources used in agriculture, being favorable to $\mathrm{P}$ losses by leaching in sandy soils or fixation in clay soils and calcareous soils (Chien et al. 2011). However, due to the constant use of mineable rock phosphate reserves worldwide, it is mandatory to optimize $\mathrm{P}$ recovery efficiency by developing fertilizers that present a greater residual effect.

The exploitation of P-rich organic residues, such as poultry litter, could be an alternative to partly replace conventional chemical phosphate fertilizers. Pyrolysis of 
poultry litter produces biochar, which is highly resistant to microbial decomposition and is a promising alternative to sanitize the material; stabilizes the carbon fraction; and concentrates nutrients, causing a slow release of P, improving the fertilizer value (Singh et al. 2012; Wang et al. 2015; Zhao et al. 2016; Lustosa Filho et al. 2017; Lustosa Filho et al. 2019). Biochar application can improve several soil properties, such as $\mathrm{pH}$, aggregation, water retention capacity, and nutrient availability (Vanek and Lehmann 2015). Thus, biochar has been shown to be a promising alternative for $\mathrm{P}$ supply, increasing nutrient use efficiency and crop production, presenting good agronomic efficiency (Ding et al. 2010; Lehmann et al. 2011; Puga et al. 2015; Chen et al. 2016a). However, in most studies, large amounts of biochar are applied and the economic feasibility can be a barrier for largescale application (El-Naggar et al. 2019).

The co-pyrolysis of biomass with minerals originates biochar-based fertilizers (BBFs), which present great potential to be used as slow-release and high-agronomic performance fertilizers (Zhao et al. 2016; Lustosa Filho et al. 2017; Lustosa Filho et al. 2019) and require much lower application rates for nutrient supply, which might enhance the economic feasibility (El-Naggar et al. 2019). Phosphate impregnation prior to pyrolysis has been shown to increase biochar yield and improve carbon stability measured by chemical and thermal oxidation methods (Carneiro et al. 2018). However, BBFs dissolve more slowly than soluble phosphate fertilizers, where practically all water-extractable $\mathrm{P}$ is released in the first $24 \mathrm{~h}$, and the dissolution rates vary among the types of phosphates used for biomass enrichment (Lustosa Filho et al. 2017). Thus, biochar enrichment with reactive rock phosphate, such as Bayóvar rock phosphate, is an option to produce BBF, since it is a raw material of relatively low cost.

Rock phosphate fertilization, however, might not be enough for plant uptake at an initial stage of growth due to its low solubility. Thus, increasing the efficiency of rock phosphates by inoculation with phosphatesolubilizing microorganisms, such as bacterial strains, could potentially increase $\mathrm{P}$ availability in the soil (Estrada et al. 2013; de Oliveira-Longatti et al. 2013; Pereira and Castro 2014; da Costa et al. 2015). Some bacteria genera, such as Pseudomonas, Bacillus, Rhizobium, Agrobacterium, Burkholderia, and Erwinia, are reported to be efficient in increasing P availability, leading to higher crop yields (Rodríguez and Fraga 1999; Khan et al. 2009; Yu et al. 2011). Bacterial strains can convert insoluble phosphates into available forms through the mineralization of the organic forms and solubilization of the inorganic forms (Sharma et al. 2013; Liu et al. 2014). According to Tao et al. (2008), the abilities of solubilization and mineralization can coexist in the same bacterial strain.
Few studies focusing on the combined use of biochar and bacterial inoculation have already been carried out (Głodowska et al. 2016; Wei et al. 2016; Rafique et al. 2017). However, none of these studies explored the effect of biochar-based Bayóvar rock phosphate fertilizer under bacterial inoculation, and besides, rock phosphates tend to be less expensive because of their simpler beneficiation over fully acidulated $\mathrm{P}$ sources, which might help to make the process economically feasible in the future. Additionally, it is important to unravel the mechanisms of $\mathrm{P}$ solubilization and mineralization in order to take advantage of this low cost and environment friendly technology. Thus, the present study was aimed to evaluate (i) the in vitro ability of five selected bacterial strains to solubilize and mineralize $P$ from a BBF enriched with Bayóvar rock phosphate and (ii) maize growth and $\mathrm{P}$ availability in an Oxisol under fertilization with BBF enriched with Bayóvar rock phosphate and bacterial inoculation under greenhouse conditions.

\section{Materials and methods \\ Biomass preparation and biochar-based fertilizer production}

Poultry litter (PL) was collected from a private farm near Lavras, Minas Gerais State, Brazil (Table 1) and owners allowed its use for research purposes. The sample was air-dried at room temperature, passed through a 20mesh sieve $(1.00 \mathrm{~mm})$, and thoroughly mixed with Bayóvar rock phosphate in powder form at the ratio of poultry litter residues/rock phosphate 1:0.5 (w/w), as described by Lustosa Filho et al. (2017) and Zhao et al. (2014). Subsequently, the blend was moistened overnight

Table 1 Selected properties of the poultry litter (PL) and the biochar-based fertilizer (BBF)

\begin{tabular}{lll}
\hline Properties & $\mathrm{BBF}$ & $\mathrm{PL}$ \\
\hline $\mathrm{pH}$ & $10.52 \pm 0.03$ & $8.10 \pm 0.01^{\mathrm{a}}$ \\
Electrical conductivity $\left(\mathrm{dS} \mathrm{m}^{-1}\right)$ & $2.10 \pm 0.07$ & $4.03 \pm 0.04$ \\
$\mathrm{CEC}\left(\mathrm{cmol}_{\mathrm{c}} \mathrm{kg}^{-1}\right)$ & $9.66 \pm 1.27$ & - \\
Carbon (\%) & $22.95 \pm 0.04$ & $36.10 \pm 0.18^{\mathrm{a}}$ \\
$\mathrm{P}_{2} \mathrm{O}_{5}$ total $\left(\mathrm{g} \mathrm{kg}^{-1}\right)$ & $265 \pm 2.67$ & $35.7 \pm 0.89^{\mathrm{a}}$ \\
$\mathrm{P}_{2} \mathrm{O}_{5} \mathrm{NAC}^{* *}$ soluble $\left(\mathrm{g} \mathrm{kg}^{-1}\right)$ & $58.0 \pm 0.29$ & - \\
$\mathrm{P}_{2} \mathrm{O}_{5}$ citric acid $\left(\mathrm{g} \mathrm{kg}^{-1}\right)$ & $59.0 \pm 1.20$ & - \\
$\mathrm{P}_{2} \mathrm{O}_{5}{\text { water-soluble }\left(\mathrm{g} \mathrm{kg}^{-1}\right)}_{\mathrm{Ca}\left(\mathrm{g} \mathrm{kg}^{-1}\right)}^{0.60 \pm 0.09}$ & - \\
$\mathrm{Mg}\left(\mathrm{g} \mathrm{kg}^{-1}\right)$ & $273.6 \pm 3.9$ & $18.63 \pm 0.60$ \\
$\mathrm{~K}\left(\mathrm{~g} \mathrm{~kg}^{-1}\right)$ & $6.88 \pm 0.15$ & $5.4 \pm 0.20^{\mathrm{a}}$ \\
$\mathrm{Al}\left(\mathrm{g} \mathrm{kg}^{-1}\right)$ & $20.85 \pm 0.75$ & $23.99 \pm 1.42$ \\
$\mathrm{Fe}\left(\mathrm{g} \mathrm{kg}^{-1}\right)$ & $0.35 \pm 0.01$ & - \\
\hline
\end{tabular}

Mean and standard deviations of three replications. ${ }^{*}$ Cation exchange

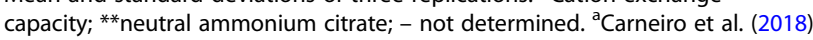


to ensure greater uniformity and oven-dried at $60{ }^{\circ} \mathrm{C}$ to constant mass prior to pyrolysis. The pre-treated sample was placed in a muffle furnace equipped with steel sealed cylinders $(10.6 \mathrm{~cm}$ diameter and $42 \mathrm{~cm}$ height), and the temperature was raised to $500{ }^{\circ} \mathrm{C}$ at a heating rate of $10{ }^{\circ} \mathrm{C} \mathrm{min}{ }^{-1}$, maintaining the target temperature for $2 \mathrm{~h}$ to allow sufficient time for complete carbonization (Zhao et al. 2014). The PL and the BBF obtained were sieved $(<2.0 \mathrm{~mm})$ and characterized (Table 1). Electrical conductivity and $\mathrm{pH}$ was determined according to Rajkovich et al. (2012) and cation exchange capacity according to Gaskin et al. (2008). The C content was determined in an automatic analyzer. Phosphorus solubility in the BBF was determined by water, citric acid solution (2\%), and neutral ammonium citrate solution ( $\mathrm{pH}$ 7.0). A more detailed description on $\mathrm{P}$ analysis can be found elsewhere (Lustosa Filho et al. 2019). Total P, Ca, Mg, K, Fe, and $\mathrm{Al}$ contents were determined by ICP-OES (Spectro Analytical Instruments, Kleve, Germany). Fourier transform infrared spectroscopy (FTIR) spectra were recorded on a Digilab Excalibur spectrometer with a spectral range $3500-400 \mathrm{~cm}^{-1}$, which were collected over an average of 32 scans (Figure S1). Interpretation of the peaks was based on other works that evaluate similar materials (Ma et al. 2015; Zhao et al. 2015; Bekiaris et al. 2016; Lustosa Filho et al. 2017).

\section{Bacterial strains}

Five selected bacterial strains isolated from common bean and cowpea nodules and belonging to the collection of the Laboratory of Soil Microbiology of the Department of Soil Science (Federal University of Lavras) were evaluated. Previous studies (Silva et al. 2012; Marra et al. 2012; de Oliveira-Longatti et al. 2013; da Costa et al. 2015; da Costa et al. 2016) already reported the origin, accession numbers of the 16S rRNA gene sequence, in vitro solubilization capacity, and plant growthpromoting characteristics of the strains (Table 2).

\section{In vitro assay}

The experiment followed a randomized complete design, with six treatments, six replicates each. The treatments consisted of inoculation using five bacterial strains: Pseudomonas sp. (UFPI B5-8A), Burkholderia fungorum (UFLA 04-155), Acinetobacter sp. (UFLA 03-09), Paenebacillus kribbensis (UFLA 03-10), and Paenibacillus sp. (UFLA 03-116), as well as a treatment non-inoculated (control). The capacity of the bacterial strains to solubilize phosphate supplied as BBF was evaluated using the National Botanical Research Institute's phosphate growth medium (NBRIP) (Nautiyal 1999) procedure, with modifications. The following composition per liter of solution was used: $10 \mathrm{~g}$ of glucose, $5 \mathrm{~g}$ of $\mathrm{MgCl}_{2} \cdot 6 \mathrm{H}_{2} \mathrm{O}, 0.25 \mathrm{~g}$ of $\mathrm{MgSO}_{4} \cdot 7 \mathrm{H}_{2} \mathrm{O}, 0.2 \mathrm{~g}$ of $\mathrm{KCl}$, and $0.1 \mathrm{~g}$ of $\left(\mathrm{NH}_{4}\right)_{2} \mathrm{SO}_{4}$. The strains were cultured in liquid medium Yeast Malt (YM) under stirring at $110 \mathrm{rpm}$ and $28{ }^{\circ} \mathrm{C}$ until reaching a cell density of $10^{8}$ colony forming unit (CFU) $\mathrm{mL}^{-1}$. Then, $1.0 \mathrm{~mL}$ of inoculum was added into $50 \mathrm{~mL}$ of NBRIP medium, containing $100 \mathrm{mg} \mathrm{L}^{-1}$ of $\mathrm{P}$ as powder BBF. The $\mathrm{pH}$ was adjusted to 7.0 before autoclaving. The flasks were then incubated for 10 days at $28{ }^{\circ} \mathrm{C}$ at $120 \mathrm{rpm}$. After incubation, samples were centrifuged at $3000 \mathrm{rpm}$ for $15 \mathrm{~min}$ and the supernatant was filtered through a $0.45-\mu \mathrm{m}$ cellulosic membrane filter. Phosphate solubilization was assessed by quantifying the soluble P concentration in the supernatant, using inductively coupled plasma optical emission spectroscopy (ICP-OES). Part of the extract was used to determine the $\mathrm{pH}$ and activity of the acid phosphatase, and another part was stored at $-80{ }^{\circ} \mathrm{C}$ for identification and quantification of organic acids.

\section{Acid phosphatase activity}

The acid phosphatase activity was determined using the methodology proposed by Juma and Tabatabai (1988). An aliquot of $100 \mu \mathrm{L}$ of the supernatant was incubated at $37{ }^{\circ} \mathrm{C}$ with $100 \mu \mathrm{L}\left(25 \mathrm{mmol} \mathrm{L}^{-1}\right)$ of $\rho$-nitrophenyl phosphate and $400 \mu \mathrm{L}$ of modified universal buffer $(\mathrm{pH}$

Table 2 Origin, identification, and solubilization of phosphates and plant growth-promoting characteristics of the strains evaluated

\begin{tabular}{|c|c|c|c|c|c|c|c|c|c|c|c|}
\hline \multirow[t]{4}{*}{ Strains } & \multirow[t]{4}{*}{ Origin } & \multirow[t]{4}{*}{ Identification } & \multirow{4}{*}{$\begin{array}{l}\text { Accession no. in } \\
\text { GenBank of the } \\
16 \mathrm{~S} \text { rRNA sequences (NCBI) }\end{array}$} & \multicolumn{6}{|c|}{$\begin{array}{l}\text { Solubilization in solid }(*) \text { and liquid }\left(^{* *}\right) \\
\text { media, }, \text {, e }\end{array}$} & \multirow{3}{*}{\multicolumn{2}{|c|}{$\begin{array}{l}\text { Plant growth-promoting } \\
\text { characteristics }{ }^{\text {, e }} \\
\text { Indole-3-acetic acid }\left(\mu \mathrm{g} \mathrm{mL}^{-1}\right) \\
\text { Tryptophan }\end{array}$}} \\
\hline & & & & \multicolumn{2}{|c|}{$\overline{\mathrm{CaHPO}_{4}}$} & \multicolumn{2}{|c|}{$\mathrm{Al}\left(\mathrm{H}_{2} \mathrm{PO}_{4}\right)_{3}$} & \multicolumn{2}{|c|}{$\mathrm{FePO}_{4} \cdot 2 \mathrm{H}_{2} \mathrm{O}$} & & \\
\hline & & & & * & $* *$ & * & ** & * & ** & & \\
\hline & & & & & & & & & & + & - \\
\hline UFLA 04-155 & $A M^{a, b}$ & Burkholderia fungorum & GU144370 & + & ND & + & ND & ND & ND & 4.53 & 6.29 \\
\hline UFLA 03-10 & $M G^{c}$ & Paenebacillus kribbensis & JQ041885 & - & - & - & - & - & + & ND & ND \\
\hline UFPI B5-8A & $P l^{d, e}$ & Pseudomonas sp. & Kj979613 & + & ND & - & ND & - & ND & 9.71 & 5.40 \\
\hline UFLA 03-116 & $M G^{c}$ & Paenibacillus sp. & JQ041897 & - & - & - & - & - & + & ND & ND \\
\hline UFLA 03-09 & $M G^{c}$ & Acinetobacter sp. & JQ041884 & + & + & - & - & - & - & ND & ND \\
\hline
\end{tabular}

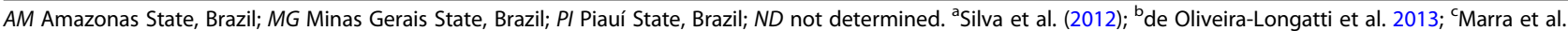

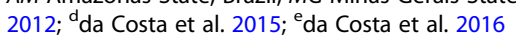


6.5). After $1 \mathrm{~h}$, the reaction was halted by adding $400 \mu \mathrm{L}$ $\mathrm{NaOH}\left(0.5 \mathrm{~mol} \mathrm{~L}^{-1}\right)$. The absorbance of the yellow color developed after the incubation was read in a spectrophotometer at $410 \mathrm{~nm}$ using a standard calibration curve of $\rho$-nitrophenol.

\section{Organic acid analysis}

Organic acid analysis was performed using highperformance liquid chromatography (HPLC) (Agilent 1220 Infinity). An aliquot of $100 \mu \mathrm{L}$ of the supernatant was injected in a chromatographic column, model Synergil Hydro-RP $80 \mathrm{~A}(250 \times 4.6 \mathrm{nmid} ; 4 \mathrm{~mm})$. The run time was $20 \mathrm{~min}$, at the flow rate of $0.7 \mathrm{~mL} \mathrm{~min}^{-1}$ at a wavelength of $220 \mathrm{~nm}$. The mobile phase was $\mathrm{KH}_{2} \mathrm{PO}_{4}$ solution $\left(20 \mathrm{mmol} \mathrm{L}^{-1}, \mathrm{pH} 2.9\right)$, used according to the analytical procedure indicated by the column manufacturer for the identification of organic acids. Certified samples of acetic, formic, malonic, oxalic, quinic, shikimic, D-malic, maleic, succinic, citric, and fumaric acids were used as analytical standards. The organic acids in the samples were quantified by calibration curves constructed with the analytical standards, relating the concentration of each acid with its respective area of absorption. Three replicates were used. The identified molecules and standard mean retention times for the acid are as follows: oxalic (3.60 min), quinic $(4.28 \mathrm{~min})$, D-malic $(5.28 \mathrm{~min})$, acetic $(7.31 \mathrm{~min})$ succinic $(11.26$ $\mathrm{min})$, fumaric $(9.64 \mathrm{~min})$, shikimic $(6.19 \mathrm{~min})$, maleic (8.55 $\mathrm{min})$, citric $(8.40 \mathrm{~min})$, salicylic $(3.70 \mathrm{~min})$, propionic (17.29 $\mathrm{min})$, and malonic (5.4 min) acids.

\section{Greenhouse experiment}

A greenhouse experiment was carried out at the Department of Soil Science of the Federal University of Lavras (Minas Gerais State, Brazil) to investigate the potential of bacterial strains to enhance maize growth and provide soluble phosphates in a P-deficient tropical Oxisol fertilized with BBF. Only three bacterial strains were selected based on their contrasting results in solubilizing phosphates in the in vitro experiment (Pseudomonas sp. UFPI B5-8A, Burkholderia fungorum UFLA 04-155, and Paenebacillus kribbensis UFLA 03-10). The experiment consisted of a factorial scheme $(5 \times 4)$, plus a positive control, conducted in a randomized block design with four replicates. The treatments consisted in five $\mathrm{P}$ doses $\left(0,50,100,200\right.$, and $400 \mathrm{mg} \mathrm{kg}^{-1}$ of $\mathrm{P}$-based on total $\mathrm{P}$ concentration in $\mathrm{BBF}$ ) combined with three bacterial strains and non-inoculated (NI). The positive control treatment $\left(200 \mathrm{mg} \mathrm{kg}^{-1}\right.$ of $\left.\mathrm{P}\right)$ was supplied as triple superphosphate (TSP) without inoculation.

Pots were filled with $3.0 \mathrm{~kg}$ of an Oxisol, collected from the 20-60 cm layer in Itumirim (Minas Gerais State, Brazil). The 0-20-cm layer was not considered for the experiment to ensure a lower concentration of organic matter in the soil to isolate the effects of BBF. The soil was air-dried, sieved $(<2.0 \mathrm{~mm})$, homogenized, and chemically characterized. Briefly, $\mathrm{P}$ was extracted by Mehlich-1, $\mathrm{pH}$ was determined in water (1:2.5, soil: solution ratio), $\mathrm{Ca}$ and $\mathrm{Mg}$ concentrations were extracted by $\mathrm{KCl} 1 \mathrm{~mol} \mathrm{~L}^{-1}$, and the organic matter content was determined by oxidation with $\mathrm{Na}_{2} \mathrm{Cr}_{2} \mathrm{O}_{7}$ and $\mathrm{H}_{2} \mathrm{SO}_{4}$. The Oxisol was defined by low $\mathrm{P}$ availability $\left(0.08 \mathrm{mg} \mathrm{dm} \mathrm{dm}^{-3}\right.$ P), low clay content (230 $\mathrm{g} \mathrm{kg}^{-1}$ clay), with soil $\mathrm{pH} 4.6$. The content of soil organic matter was $7.9 \mathrm{~g} \mathrm{~kg}^{-1}$ and $\mathrm{Ca}^{2+}$ and $\mathrm{Mg}^{2+}$ concentrations were 0.24 and $0.12 \mathrm{cmol}_{\mathrm{c}}$ $\mathrm{dm}^{-3}$, respectively. Liming was performed to increase the base saturation to $60 \%$ using calcium carbonate $\left(\mathrm{CaCO}_{3}\right)$ and magnesium carbonate $\left(\mathrm{MgCO}_{3}\right)$ at a 3:1 molar ratio. The soil was incubated for 20 days with moisture of approximately $70 \%$ of the field capacity. After the incubation period, the P doses were applied in the form of BBF powder, as well as basic fertilization in solution form. The basic fertilization consisted in 200 mg of $\mathrm{N}\left[\left(\mathrm{KNO}_{3}\right.\right.$ and $\left.\left.\left(\mathrm{NH}_{4}\right)_{2} \mathrm{SO}_{4}\right)\right], 200 \mathrm{mg}$ of $\mathrm{K}\left(\mathrm{KNO}_{3}\right.$ and $\mathrm{KCl}), 40 \mathrm{mg}$ of $\mathrm{S}\left[\left(\mathrm{NH}_{4}\right)_{2} \mathrm{SO}_{4}\right], 1.5 \mathrm{mg}$ of $\mathrm{Cu}$ $\left(\mathrm{CuSO}_{4} \cdot 5 \mathrm{H}_{2} \mathrm{O}\right), 3.5 \mathrm{mg}$ of $\mathrm{Mn}\left(\mathrm{MnCl}_{2} \cdot 4 \mathrm{H}_{2} \mathrm{O}\right), 5.0 \mathrm{mg}$ of $\mathrm{Zn}\left(\mathrm{ZnSO}_{4} \cdot 7 \mathrm{H}_{2} \mathrm{O}\right), 0.8 \mathrm{mg}$ of $\mathrm{B}\left(\mathrm{H}_{3} \mathrm{BO}_{3}\right), 0.1 \mathrm{mg}$ of $\mathrm{Mo}$ $\left(\mathrm{Na}_{2} \mathrm{MoO}_{4} \cdot 2 \mathrm{H}_{2} \mathrm{O}\right)$, and $3.0 \mathrm{mg}$ of $\mathrm{Fe}\left(\mathrm{FeCl}_{3}\right)$ per kilogram of soil. Then, soil was completely homogenized and incubated for 20 days with moisture of approximately $70 \%$ of the field capacity. Nitrogen and potassium fertilization were divided into three equal applications via fertigation at planting and 15 and 30 days after planting.

Maize (Zea mays L., hybrid BM 915 PRO) seeds were sterilized using $98 \%$ ethanol (30 s) and $2 \%$ sodium hypochlorite $(2 \mathrm{~min})$ and successively washed in distilled water. The seeds were placed in sterilized Petri dishes with moistened cotton and filter paper, where they remained for $72 \mathrm{~h}$ at $28{ }^{\circ} \mathrm{C}$ until the emergence of rootlets. After the last incubation period, four seeds were sown per pot and each seed received $2 \mathrm{~mL}$ of bacterial culture at the dose of $2 \times 10^{8} \mathrm{CFU}$ seed $^{-1}$, grown in liquid medium YM, as previously described. After 6 days, only one plant was left in each pot. Soil moisture was kept at approximately $70 \%$ of the field capacity and water was replaced daily by weight.

\section{Count of calcium phosphate-solubilizing microorganisms in the soil}

After the lime amendment, a single soil sample was collected from 20 pots to form a composite sample in order to estimate the number of phosphate-solubilizing microorganisms present in soil, before the experiment was implemented. Ten grams of soil was diluted in $90 \mathrm{~mL}$ of saline solution $\left(8.5 \mathrm{~g} \mathrm{~L}^{-1} \mathrm{NaCl}\right)$ to form a homogeneous suspension. From this suspension, serial dilutions $\left(10^{-1}\right.$ up to $10^{-10}$ ) were performed, and $100 \mu \mathrm{L}$ of each dilution was plated in the solid NBRIP medium. The plates 
were incubated at $28{ }^{\circ} \mathrm{C}$ and colony counts were periodically conducted until the end of the incubation period (10 days). Several microbial groups were observed, but no calcium phosphate-solubilizing microorganisms were identified since it was not observed in the presence of a transparent halo, which is a characteristic of phosphate solubilization.

\section{Plant sampling and analysis}

After 45 days of sowing, shoots were harvested and oven-dried at $65{ }^{\circ} \mathrm{C}$ for $72 \mathrm{~h}$. After that, shoot dry matter (SDM) was determined and analyzed for its chemical composition. Shoot tissues were digested in an open block digestion system using concentrated nitricperchloric acid solution $\left(2 \mathrm{~mL} \mathrm{HClO}+4 \mathrm{~mL} \mathrm{HNO}_{3}\right)$, diluted to $50 \mathrm{~mL}$ using deionized water, and $\mathrm{P}$ levels were measured by ICP-OES. The P uptake was obtained by multiplying the $\mathrm{P}$ concentration times SDM production.

\section{Soil chemical and biological analysis}

After harvesting, a soil sample from the center of each pot $(10 \mathrm{~cm}$ depth) was collected to determine acid/alkaline phosphatase activity. Additionally, samples of rhizosphere soil (adhered to roots) and bulk soil were taken from each pot to determine $\mathrm{pH}\left(\mathrm{H}_{2} \mathrm{O}\right)$ and available $\mathrm{P}$ by anion exchange resin. These samples were air-dried, sieved $(<2.0 \mathrm{~mm})$, and homogenized prior to analysis. The phosphatase activity was determined using para-nitrophenyl phosphate as the analogue substrate. A sample of $1.0 \mathrm{~g}$ of soil was incubated $\left(37^{\circ} \mathrm{C}\right.$ for $\left.1 \mathrm{~h}\right)$ with $4.0 \mathrm{~mL}$ of a buffer solution (modified universal buffer, $\mathrm{pH} 6.5$ for the acid phosphatase and $\mathrm{pH} 11$ for the alkaline phosphatase) and $1.0 \mathrm{~mL}$ of para-nitrophenyl phosphate $\left(0.025 \mathrm{~mol} \mathrm{~L}^{-1}\right)$. Then, $1.0 \mathrm{~mL}$ of $\mathrm{CaCl}_{2}\left(0.5 \mathrm{~mol} \mathrm{~L}^{-1}\right)$ and $4 \mathrm{~mL}$ of $\mathrm{NaOH}\left(0.5 \mathrm{~mol} \mathrm{~L}^{-1}\right)$ were added to halt the reaction. The absorbance of the yellow color developed after the incubation period was measured in a spectrophotometer at $410 \mathrm{~nm}$ using a standard calibration curve of para-nitrophenyl (Juma and Tabatabai 1988).

\section{Data analysis}

All experimental data were checked for normality by the Shapiro-Wilk's test prior to other data analysis. Data from the in vitro experiment were submitted to analysis of variance, and the means of the treatments were grouped by the Scott-Knott test $(p \leq 0.05)$. Pearson correlations were performed between $\mathrm{P}$ concentration in NBRIP, $\mathrm{pH}$, and phosphatase activity $(p \leq 0.05)$. Data from the greenhouse experiment were submitted to analysis of variance, and the means of the combinations were grouped by the Scott-Knott test $(p \leq 0.05)$. The additional control was compared with the factorial mean by the $F$ test $(p \leq 0.05)$.

\section{Results}

\section{Properties of the PL and BBF}

The pyrolysis of PL enriched with Bayóvar rock phosphate caused mainly an increase in the $\mathrm{pH}$ value of the corresponding BBF (from 8.10 in PL to 10.52 in $\mathrm{BBF}$ ) (Table 1). Moreover, there was a substantial increase in total $\mathrm{P}$ and $\mathrm{Ca}$ due to the composition of Bayóvar rock phosphate. Other elements, such as C, $\mathrm{K}$, and $\mathrm{Fe}$, were reduced in the $\mathrm{BBF}$ when compared with PL due to the dilution effect. Phosphorus solubility in NAC and citric acid (2\%) was $\sim 22 \%$ of total $\mathrm{P}$, while water-soluble $\mathrm{P}$ of the BBF was extremely low. The solubility results show the slow-release behavior of $\mathrm{P}$ from the BBF.

The FTIR spectra of the BBF is presented in Figure S1 and showed $\mathrm{CO}_{2}$ and $\mathrm{C}=\mathrm{O}$ compounds in the broad region of $2350 \mathrm{~cm}^{-1}$. Peaks around 1400 to $1600 \mathrm{~cm}^{-1}$ indicate the presence of $\mathrm{C}=\mathrm{C}, \mathrm{C}-\mathrm{O}$, and $\mathrm{CO}_{2}{ }^{3-}$, while peaks in the region of 460 to $860 \mathrm{~cm}^{-1}$ correspond to phosphate groups as a result of rock phosphate addition.

\section{In vitro assay: phosphate solubilization, $\mathrm{pH}$, and acid phosphatase activity}

The bacterial strains were able to solubilize $\mathrm{P}$ in a liquid NBRIP medium supplied with BBF. At the end of incubation, the non-inoculated treatment (control) exhibited lower soluble $\mathrm{P}$ concentration $\left(9.33 \mathrm{mg} \mathrm{L}{ }^{-1}\right)$, without abrupt change in supernatant $\mathrm{pH}$ (6.68). Bacterial inoculation caused a significant drop in the liquid NBRIP supernatant $\mathrm{pH}$. Consequently, there was an increase in soluble $\mathrm{P}$ concentration (up to 41.4), in the following treatment order: UFLA 03-09 > UFLA 04-155 = UFPI B5-8A > UFLA 03-10 = UFLA 03-116 > control (Fig. 1a). The strain UFLA 03-09 presented the highest concentration of $\mathrm{P}$, which was approximately 4.5 -fold higher than the control.

The maximum drop in $\mathrm{pH}$ was recorded for the strain UFLA 04-155 (2.95), followed by UFLA 03-09 (3.55) and UFPI B5-8A (3.80) (Fig. 1b). Therefore, a strong negative correlation was observed between $\mathrm{pH}$ and soluble $\mathrm{P}$ concentration in liquid NBRIP medium $(r=-0.91 * *)$. Although the strain UFLA 03-09 presented the best result in the in vitro assay, it was not selected for the greenhouse experiment due to its capacity to act as a human pathogen.

The bacterial strains showed a low activity of acid phosphatase in liquid NBRIP medium. However, the strains UFLA 03-10, UFPI B5-8A, and UFLA 04-155 differed significantly from the control (Fig. 1c). Phosphatase activity was up to $68 \mu \mathrm{mol}$ para-nitrophenyl phosphate $\mathrm{L}^{-1}$, with the following treatment order: UFLA 03-10 > UFPI B5-8A = UFLA 04-155 > UFLA 03$116=$ UFLA $03-09=$ control. The strain UFLA 03-10 presented acid phosphatase activity five times higher than the control. However, there was no correlation 

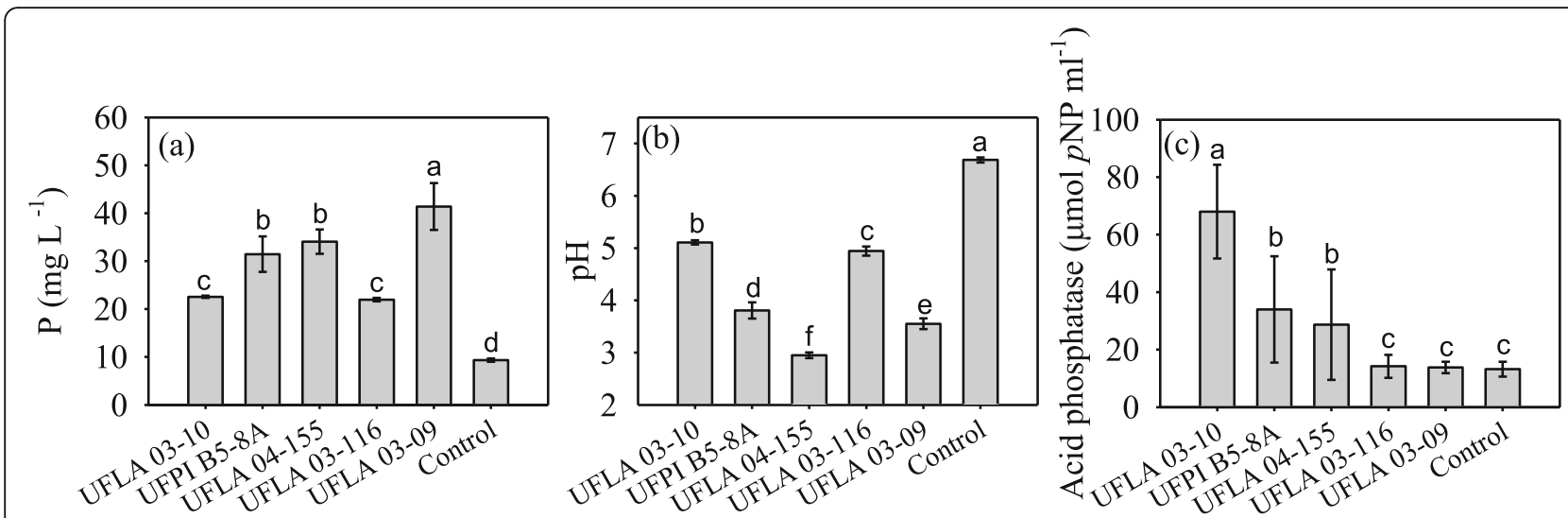

Fig. 1 Soluble $\mathrm{P}(\mathbf{a}), \mathrm{pH}(\mathbf{b})$, and acid phosphatase activity (c) in the liquid NBRIP medium containing biochar enriched with Bayóvar rock phosphate (100 mg L $\mathrm{L}^{-1}$ P) 10 days after inoculation of phosphate-solubilizing bacteria. Control, uninoculated treatment; pNP, para-nitrophenyl phosphate. Means followed by the same letter do not differ by the Scott-Knott test $(p<0.05)$. Means and standard deviations of six replications

between soluble $\mathrm{P}$ concentration and acid phosphatase activity $(r=-0.01 \mathrm{~ns})$.

\section{In vitro assay: identification and quantification of organic} acids

The following organic acids were detected: oxalic, quinic, D-malic, acetic, succinic, citric, and lactic (Table 3). Relevantly, quinic acid was produced by all strains, followed by oxalic acid produced by UFPI B58A, UFLA 04-155, UFLA 03-116, and UFLA 03-09 strains, while lactic acid was produced only by the strain UFLA 04-155.

\section{Maize growth and $\mathrm{P}$ uptake}

The $\mathrm{P}$ doses applied as BBF increased SDM production and $\mathrm{P}$ uptake by maize plants, with higher values at the dose of $400 \mathrm{mg} \mathrm{kg}^{-1}$ of P (Fig. 2). The positive control promoted higher amounts in both SDM and $\mathrm{P}$ uptake compared with the factorial mean. However, the dose of $400 \mathrm{mg} \mathrm{kg}$-1 of $\mathrm{P}$ presented a much higher SDM production when compared to the negative control (Fig. 2a). Also, when compared with the positive control, this dose promoted 30\% lower SDM yield. The dose $400 \mathrm{mg} \mathrm{kg}^{-1}$ of $\mathrm{P}$ provided $\mathrm{P}$ uptake 76 times higher when compared with the absence of P fertilization (Fig. 2b). This dose showed a P uptake $88 \%$ lower when compared with the positive control. In the dose $400 \mathrm{mg} \mathrm{kg}^{-1}$ of $\mathrm{P}$, the strain UFPI B5-8A increased SDM production when compared with the other strains and NI, promoting an increase of $21 \%$ when compared with NI. There was no difference in $\mathrm{P}$ uptake by bacterial inoculation regarding $\mathrm{P}$ doses.

\section{Acid/alkaline phosphatase and bulk and rhizosphere soil $\mathrm{pH}$}

The addition of $\mathrm{P}$ increased acid phosphatase activity; however, bacterial inoculation did not affect this enzyme in any $\mathrm{P}$ doses (Fig. 3a). The highest activities of acid phosphatase were observed from the dose 100 $\mathrm{mg} \mathrm{kg}^{-1}$ of $\mathrm{P}$, which presented approximately activity

Table 3 Concentration of low molecular weight organic acids in the liquid NBRIP medium containing biochar enriched with phosphate Bayóvar (100 $\mathrm{mg} \mathrm{L}^{-1}$ of P) as a function of the inoculation of phosphate-solubilizing bacteria

\begin{tabular}{|c|c|c|c|c|c|c|}
\hline Organic acids (pKa) & $\begin{array}{l}\text { UFLA 03-10 } \\
\mu \mathrm{mol} \mathrm{L}\end{array}$ & UFPI B5-8A & UFLA 04-155 & UFLA 03-116 & UFLA 03-09 & Control $^{a}$ \\
\hline Oxalic (1.23) & - & $763 \pm 14.1$ & $1618 \pm 52.7$ & $185 \pm 22.8$ & $1082 \pm 395$ & $149 \pm 36.9$ \\
\hline Quinic (3.46) & $1297 \pm 66.7$ & $446 \pm 121$ & $969 \pm 149$ & $173 \pm 102$ & $600 \pm 126$ & $261 \pm 99.0$ \\
\hline D-malic (3.40) & - & - & - & $431 \pm 248$ & - & - \\
\hline Acetic (4.76) & $59.6 \pm 4.1$ & - & - & $61.5 \pm 1.80$ & - & - \\
\hline Succinic (4.16) & $676 \pm 393$ & $140 \pm 19.5$ & - & $395 \pm 16.7$ & - & - \\
\hline Citric (3.14) & $84.1 \pm 16.6$ & - & - & - & - & $20.0 \pm 3.70$ \\
\hline Lactic (3.08) & - & - & $353.6 \pm 63.7$ & - & - & - \\
\hline Total & $2116 \pm 481$ & $1350 \pm 154$ & $2941 \pm 265$ & $1245 \pm 391$ & $1683 \pm 521$ & $431 \pm 139$ \\
\hline
\end{tabular}



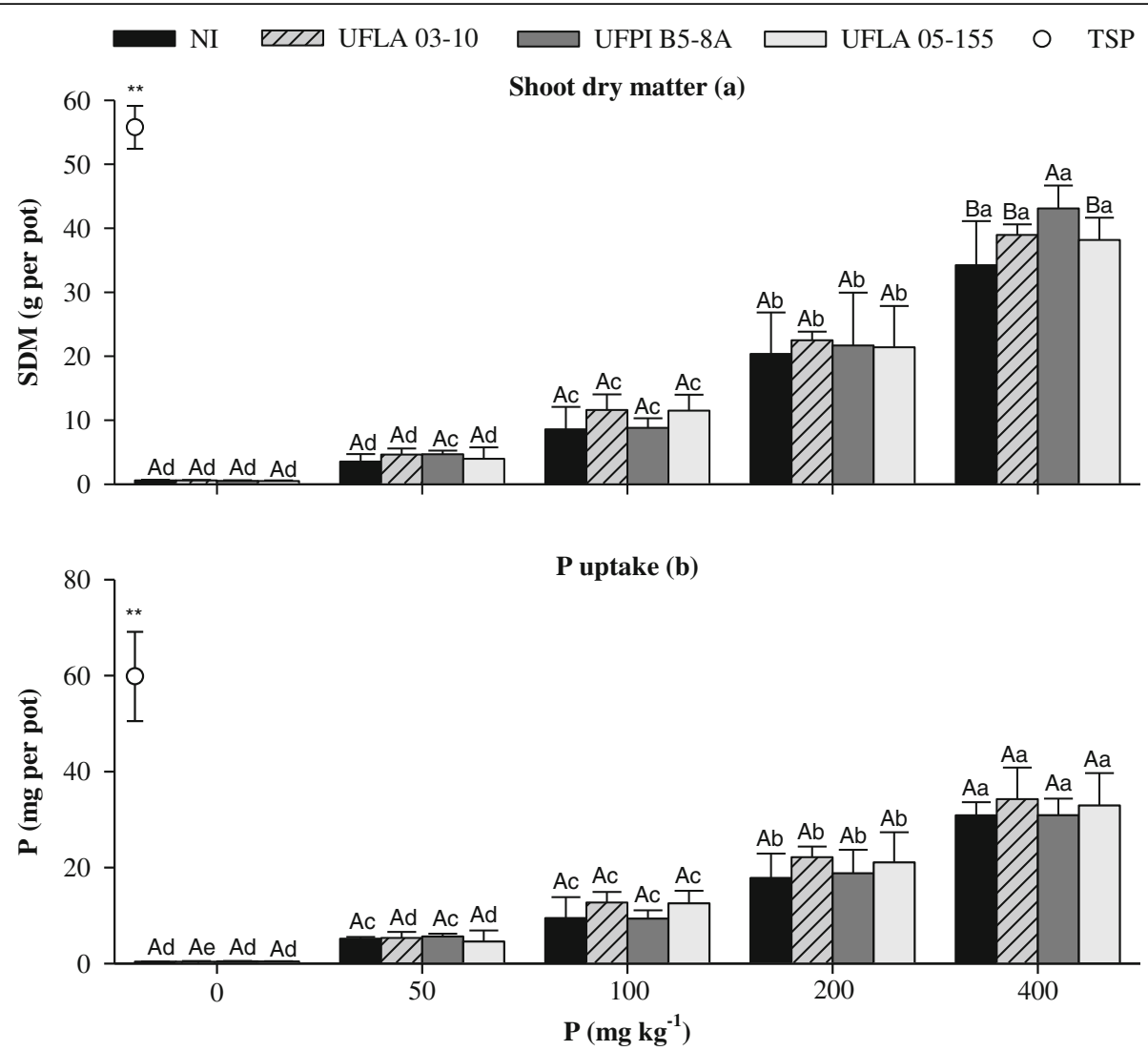

Fig. 2 Maize shoot dry matter (a) and P uptake (b) as a function of P doses (biochar enriched with Bayóvar rock phosphate) and phosphatesolubilizing bacteria inoculation. Two asterisks indicate significant at $p<0.05$. Uppercase letters compare strains within each $\mathrm{P}$ dose and lowercase letters compare P doses within each strain by the Scott-Knott test $(p<0.05)$. Means and standard deviations of four replications. TSP $=$ $200 \mathrm{mg}$ P of triple superphosphate $\mathrm{kg}^{-1}$ soil

$50 \%$ higher when compared with the absence of $\mathrm{P}$ fertilization. The $\mathrm{P}$ doses did not affect alkaline phosphatase activity. However, in the dose $50 \mathrm{mg} \mathrm{kg}^{-1}$ of $\mathrm{P}$, higher activities in the strain UFLA 03-10 and NI were observed (Fig. 3b). In general, a strong effect of $\mathrm{P}$ doses and bacterial inoculation in $\mathrm{pH}$ of both bulk and rhizosphere soils was not observed (Fig. 4). However, there was a slight decrease in bulk and rhizosphere soil $\mathrm{pH}$ at the dose $50 \mathrm{mg} \mathrm{kg}^{-1}$ of $\mathrm{P}$.

\section{Available $\mathbf{P}$ in rhizosphere and bulk soil}

The $P$ doses and bacterial inoculation increased available $\mathrm{P}$ in soil (Fig. 5). The dose $400 \mathrm{mg} \mathrm{kg} \mathrm{kg}^{-1}$ of $\mathrm{P}$ as $\mathrm{BBF}$ presented available $\mathrm{P}$ ten times higher in bulk and six times higher in rhizosphere when compared with the absence of $\mathrm{P}$ fertilization. Regarding the types of inoculation in bulk soil, the strains UFLA 03-10 and UFLA 04-155 increased available $P$ in nearly $14 \%$ and $12 \%$, respectively, when compared with NI in the dose of $400 \mathrm{mg} \mathrm{kg}^{-1}$ of P (Fig. 5a). However, in rhizosphere soil in the same dose, all strains significantly increased available $\mathrm{P}$ when compared with NI, presenting increases of $23 \%, 21 \%$, and $27 \%$, for the strains UFLA 03-10, UFPI B5-8A, and UFLA 04-155, respectively (Fig. 5b).

\section{Discussion}

This study showed that inoculation with selected phosphate-solubilizing bacterial strains, such as the strain UFPI B5-8A, resulted in an increase in maize SDM under $\mathrm{P}$ supply as BBF, either by phosphate solubilization or other mechanisms that promote plant growth. Inoculation with phosphate-solubilizing microorganism has shown to be effective due to these strains' capacity to enhance soil available P. Tropical soils have low natural availability of $\mathrm{P}$ and presents high concentrations of insoluble $\mathrm{Fe}$ and $\mathrm{Al}$ phosphates. However, the phosphate-solubilizing bacteria selected in this study are more efficient in solubilizing $\mathrm{Ca}$ phosphate, which is present in the BBF as Bayóvar rock phosphate. Consequently, BBF fertilization and selected bacterial strain inoculation constitute an important strategy for providing sustainable alternatives to the water-soluble phosphate fertilizers such as TSP, which has a high energy cost for 


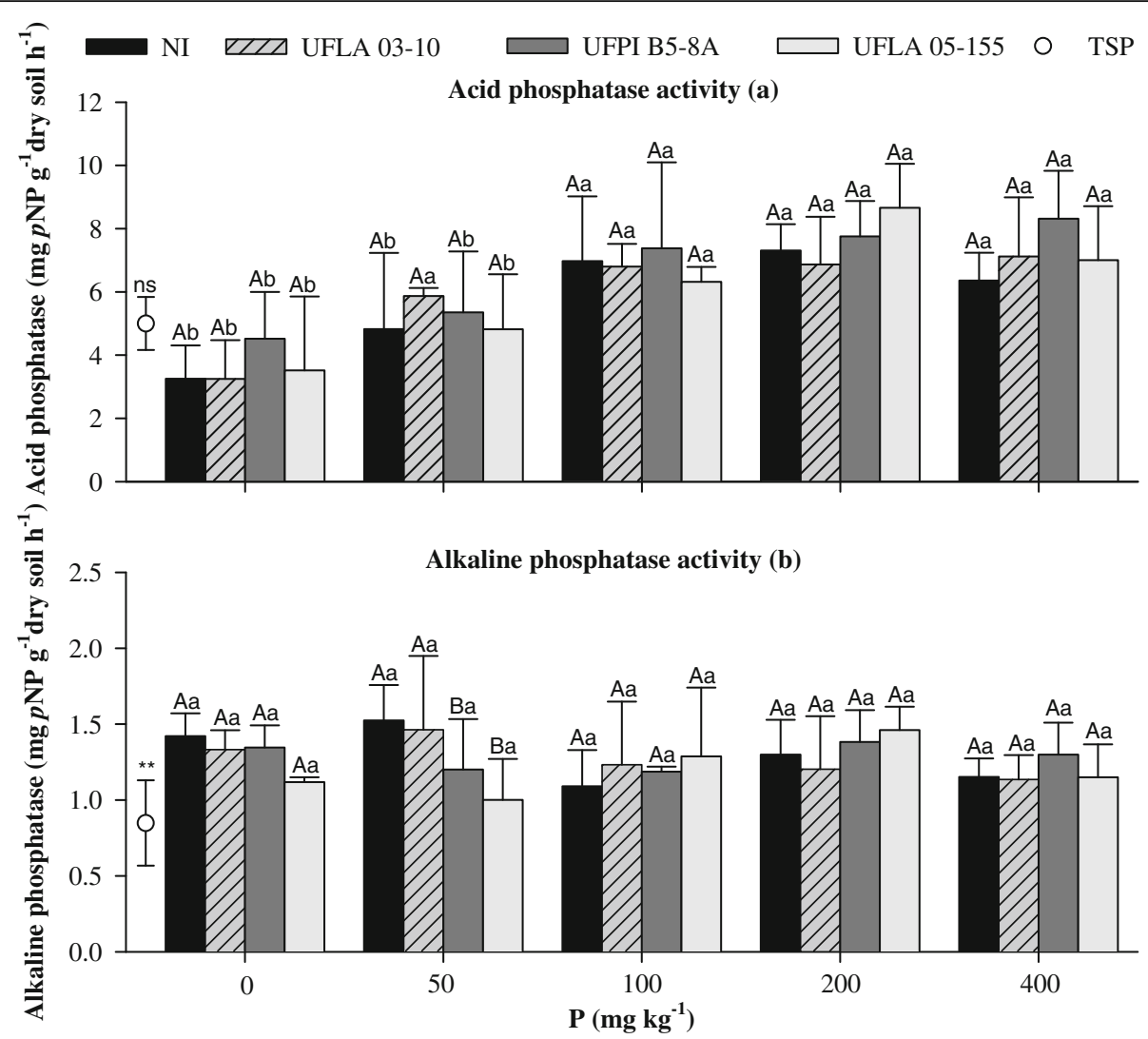

Fig. 3 Acid phosphatase activity (a) and alkaline phosphate activity (b) as a function of P doses (biochar enriched with Bayóvar rock phosphate) and phosphate-solubilizing bacterial inoculation. Two asterisks indicate significant at $p<0.05$. ns, no significant; $\rho N P$, paranitrophenyl phosphate. Uppercase letters compare strains within each $P$ dose and lowercase letters compare $P$ doses within each strain by the Scott-Knott test $(p<0.05)$. Means and standard deviations of four replications. TSP $=200 \mathrm{mg} P$ of triple superphosphate $\mathrm{kg}^{-1}$ soil

its production. This combination aiming to achieve satisfactory plant growth has been reported as a promising approach for crop production (Rafique et al. 2017). Indigenous isolated bacterial strains increased nutrient uptake by French beans, maize, and rice plants (Saxena et al. 2013; Deb et al. 2016; Rafique et al. 2017). The variety of nutrients, as well as the surface area and highly porous nature of biochar, reflect its ability to act as a safe environment for microorganisms, which is one of the main reasons of changes in soil properties and the increase of nutrient uptake by plants (Nigussie et al. 2012). Furthermore, it is well known that biochar acts as a soil conditioner by improving moisture content and nutrient availability (Chen et al. 2010; Nigussie et al. 2012; Nguyen et al. 2017).

Several authors have suggested that biochar addition to soil promotes increases of phosphate-solubilizing bacteria genera through changes in $\mathrm{C}$ fluxes and for providing pores to accommodate these microorganisms, protecting them against predators in soil (Warnock et al. 2007; Anderson et al. 2011; Fox et al. 2016; Zhang et al. 2018). Other studies have demonstrated that phosphate- solubilizing bacteria are effective in enhancing growth and P uptake by maize (Kaur and Reddy 2014; Pereira and Castro 2014) and rice plants (da Costa et al. 2015). Also, da Costa et al. (2015) provided enough evidence of the positive effect of rock phosphate fertilization and phosphate-solubilizing bacterial inoculation with strains used in our study. However, plant growth promotion by bacterial inoculation does not always result in an increase on nutrient accumulation in plant tissues (Pereira and Castro 2014). Additional processes that promote plant growth can be attributed as the ability to inhibit the growth of phytopathogens and the production of plant growth hormones (de Oliveira-Longatti et al. 2013).

The capacity of the inoculated strains to provide available $\mathrm{P}$ in the soil should be emphasized, since BBF is up to five times less soluble in ammonium neutral citrate than TSP. However, P solubilization did not necessarily resulted in shoot dry matter production in treatments inoculated with the strains UFLA 03-10 and UFLA 04155. On the initial stage of growth, plants might require a constant nutrient supply and strain solubilization can 

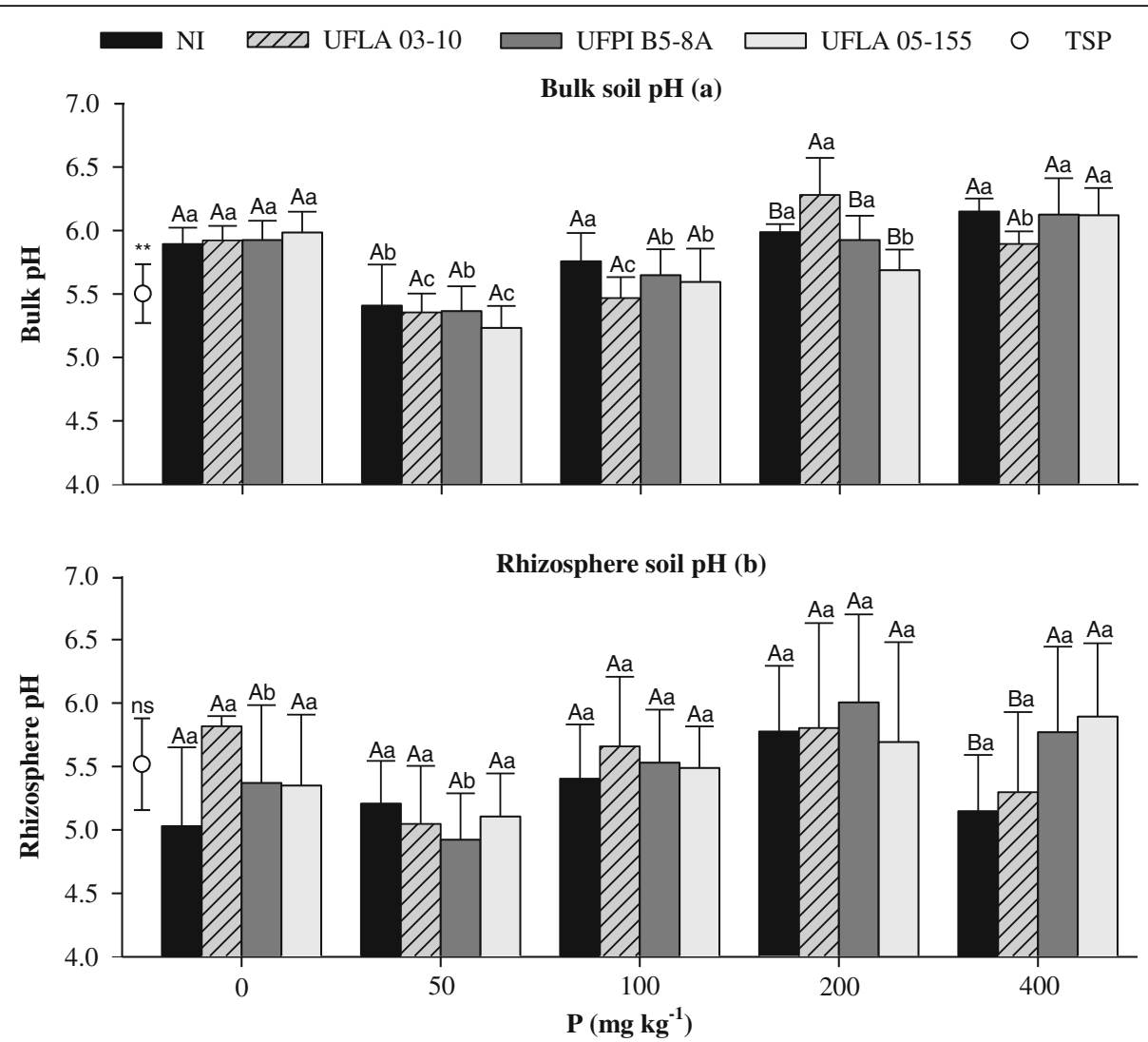

Fig. 4 Bulk soil pH (a) and rhizosphere soil pH (b) as a function of P doses (biochar enriched with Bayóvar rock phosphate) and phosphatesolubilizing bacterial inoculation. Two asterisks indicate significant at $p<0.05$. ns, no significant. Uppercase letters compare strains within each $\mathrm{P}$ dose and lowercase letters compare P doses within each strain by the Scott-Knott test $(p<0.05)$. Means and standard deviations of four replications. TSP $=200 \mathrm{mg}$ P of triple superphosphate $\mathrm{kg}^{-1}$ soil

be limited by its ability on short-term solubilization. The soil dilution effect can also explain this behavior, since BBF was entirely mixed in the soil volume and inoculation was dependent on the root system growth to access the $\mathrm{P}$ source and perform solubilization. Rhizosphere soil is highly influenced by root activity, and bacterial colonization is positively affected by plant root exudates, ensuring its survival and solubilization profile. It is important to emphasize that in vitro activity will not always correlate with in vivo effects on plant development and available P. In our study, for example, the strain UFLA 03-10 was less efficient in releasing $P$ in the in vitro assay when compared with the in vivo experiment. One of the reasons can be attributed to liquid NBRIP medium composition, which provides only one carbon source and it may not be the major source required by this strain to incorporate into its microbial biomass and operate better in P solubilization. In vivo assays provide a different environment for microbial colonization, mostly by root exudates and the variety of carbon sources (Jacoby et al. 2017). Therefore, the same result in both assays should not be expected.
Our findings report that bacterial inoculation caused a decrease in liquid NBRIP medium $\mathrm{pH}$ resulting in $\mathrm{P}$ solubilization, similarly as described by $\mathrm{Yu}$ et al. (2012). The ability of these strains in releasing $\mathrm{P}$ supplied by BBF had never been previously tested. However, phosphate solubilization by these strains has already been assessed (Marra et al. 2012; de Oliveira-Longatti et al. 2013; da Costa et al. 2016). The amount of P solubilization depends mainly on the strain, the carbon source, the production of organic acids, and the types of insoluble phosphates provided (Alexander 1961; Marra et al. 2019). Phosphate mineralization was low in liquid NBRIP medium. However, acid phosphatase analysis was performed only at the end of incubation, not being possible to detect its maximum activity during this period. Thus, soluble P may have come from both solubilization and mineralization processes. Acid phosphatase activity mainly participates in the mineralization of organic phosphates (Richardson 2002; Richardson et al. 2009). However, due to the dephosphorylating action, acid phosphatase activity could indirectly influence inorganic $\mathrm{P}$ solubilization by lowering the medium $\mathrm{pH}$ (Achal 

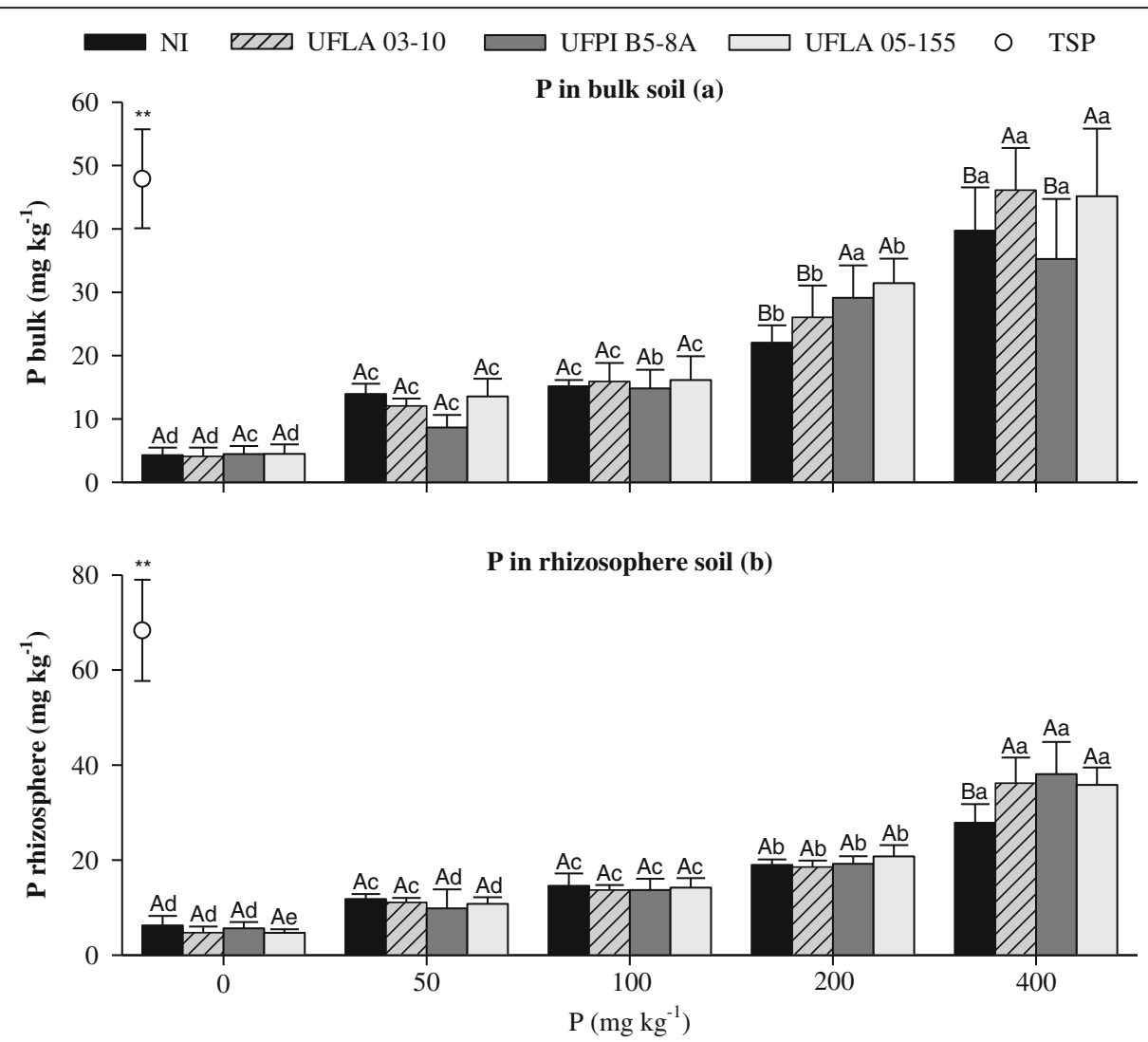

Fig. 5 Available $\mathrm{P}$ in bulk soil (a) and in rhizosphere soil (b) as a function of P doses (biochar enriched with Bayóvar rock phosphate) and phosphate-solubilizing bacterial inoculation. Two asterisks indicate significant at $p<0.05$. Uppercase letters compare strains within each $P$ dose and lowercase letters compare P doses within each strain by the Scott-Knott test $(p<0.05)$. Means and standard deviations of four replications. TSP $=200 \mathrm{mg}$ P of triple superphosphate $\mathrm{kg}^{-1}$ soil

et al. 2007). The lack of correlation between soluble $\mathrm{P}$ concentration and acid phosphatase activity may indicate that other mechanisms are involved. Another explanation for the low acid phosphatase activity is that its synthesis is stimulated only when the soluble inorganic $\mathrm{P}$ level is limited (Dick and Dos-Santos 2011), and, in this case, phosphate solubilization during incubation may have inhibited its activity.

In soil, BBF application tends to promote a natural correction of soil leading to higher $\mathrm{pH}$ values with a tendency to increase alkaline phosphatase activity and decrease acid phosphatase activity (Bera et al. 2016; Bornø et al. 2018). In the present study, an increase in alkaline phosphatase activity was not observed, mainly because the $\mathrm{P}$ doses applied as BBF did not raise the soil $\mathrm{pH}$ higher than 9.0 to activate and increase the activity of this enzyme (Eivazi and Tabatabai 1977; Herbien and Neal 1990). Acid and alkaline phosphatases can coexist within different ranges of soil $\mathrm{pH}$. In tropical, naturally acidic soils, acid phosphatase is more representative, while the alkaline phosphatase is typically measured at high $\mathrm{pH}$, far from the natural typically found soil $\mathrm{pH}$ values (Margalef et al. 2017).

It is reported that inorganic phosphate-solubilizing activity is mainly associated with the release of low molecular weight organic acids or proton extrusion by microbial cellular respiration and ammonium absorption (Illmer and Schinner 1992; Chen et al. 2006, 2016b; Marra et al. 2019). The organic acids released can dissociate, releasing $\mathrm{H}^{+}$and organic anions, which may act as a chelate trapping cations, such as $\mathrm{Ca}^{2+}$, or even occupying the exchange sites on soil clays preventing $\mathrm{P}$ adsorption (Bolan et al. 1994; Ali and Dzombak 1996; Geelhoed et al. 1999; Strom et al. 2001). The oxidation of glucose to organic acids results in acidification around bacterial cell, favoring phosphate solubilization (Kpomblekou and Tabatabai 1994). In previous studies, the strain UFLA 03-09 mainly released tartaric acid and the strain UFLA 03-10, tartaric and citric acids, while the strain UFLA 03-116 did not release organic acids in the medium containing glucose as the carbon source and tricalcium phosphate as the P source (Marra et al. 2019). 
Nevertheless, the strain UFLA 03-116 was reported to release gluconic and oxalic acids in liquid GELP medium with $\mathrm{CaHPO}_{4}$ as $\mathrm{P}$ source (Marra et al. 2012), indicating that the insoluble $\mathrm{P}$ source, along with the medium composition, may influence the type of organic acid released. These same strains produced other types of organic acids when the carbon source of the medium was changed (Marra et al. 2019).

In this assay, the strains UFLA 04-155, UFPI B5-8A, and UFLA 03-09 acidified the medium and high amount of soluble P was quantified. Thus, $\mathrm{P}$ was released mainly by acidification (organic acids or proton extrusion). Other researchers also found a negative correlation between $\mathrm{pH}$ and soluble $\mathrm{P}$, indicating that acidification could possibly facilitate $\mathrm{P}$ solubilization (Park et al. 2011). These strains released the highest concentrations of oxalic acid, which has the lowest $\mathrm{pKa}$ of the detected organic acids rendering the lowest $\mathrm{pH}$, which better explains the $\mathrm{P}$ release from these strains. However, the strains UFLA 03-10 and UFLA 03-116 withhold the medium $\mathrm{pH}$ at around 5, indicating that acidification was not the only mechanism used to promote solubilization, and the acids may be present in anionic forms playing a major role in $\mathrm{Ca}^{2+}$ chelation rather than acidification of the medium (Jones 1998; Park et al. 2011; Marra et al. 2011). Thus, other solubilization mechanisms, such as siderophores and exopolysaccharide production, may be indirectly involved (Hamdali et al. 2008; Yi et al. 2008). The strains UFLA 03-116 and UFLA 03-10 were reported as producers of large amounts of exopolysaccharide and low amounts of organic acids (Marra et al. 2012, 2019).

Acidulated $\mathrm{P}$ sources are entirely soluble, decreasing $\mathrm{P}$ use efficiency in tropical soils. However, BBF is a slowrelease fertilizer, and together with phosphatesolubilizing bacteria, it may contribute to the gradual availability of $\mathrm{P}$, preventing or decreasing $\mathrm{P}$ loss. Besides, the current study provides evidence that it is possible to gradually replace chemical fertilizers by biofertilizers, or, at least, we present evidence that part of the $\mathrm{P}$ available can be provided from a low-soluble P source in combination with bacterial P solubilization activity. However, optimizations in the cultivation system ought to be better defined. BBF produced from poultry litter promotes a better final destination of its nutrients composition, reducing the environmental impact of incorrect disposal. Although inoculation increased soil $\mathrm{P}$ availability, BBF efficiency would be limited for annual crops, since plants require large amounts of readily available $\mathrm{P}$, which is not supplied by BBF due to its slow-release nature and the short-term solubilization by bacterial strains. In this situation, the chemical fertilizers could be partially or entirely substituted for perennial crops, since a residual effect is essential since the culture remains longer in the area.

\section{Conclusions}

Bacterial inoculation significantly enhanced maize growth and available $\mathrm{P}$ in a $\mathrm{P}$-deficient tropical Oxisol under $\mathrm{P}$ supply as biochar-based fertilizer. The strains UFLA 03-10, UFLA 04-155, and UFPI B5-8A were found to be efficient in solubilizing phosphate from BBFs, making it accessible for plant uptake and other microorganisms, becoming a promising future alternative as biofertilizers to achieve similar benefits of soluble phosphate fertilizers or progressively reduce its inputs in soil.

\section{Supplementary information}

Supplementary information accompanies this paper at (https://doi.org/10. 1186/s13213-020-01550-3).

Additional file 1: Figure S1. Fourier transform infrared spectroscopy (FTIR) spectra (3500-400 $\mathrm{cm}^{-1}$ ) of the biochar-based rock phosphate fertilizer (BBF). ${ }^{a}$ Phosphate groups: $\mathrm{P}-\mathrm{O}-\mathrm{P}, \mathrm{P}-\mathrm{O}, \mathrm{P}=\mathrm{O}, \mathrm{P}-\mathrm{O}^{-}, \mathrm{PO}_{4}{ }^{3-}$. a.u: arbitrary unit.

\section{Acknowledgements}

The authors are grateful to Dr. Carlos Alberto Silva (Federal University of Lavras) and Dr. Sara Dantas Rosa for the organic acid analysis. This work was funded partially by the National Council for Scientific and Technological Development (CNPq - Grant 404076/2016-5), the Research Foundation of the State of Minas Gerais (FAPEMIG_-Grant APQ-00484-14), and the Coordination for the Improvement of Higher Education Personnel (CAPES-Proex 5902014). The first author received a Master's scholarship from CAPES. FMS Moreira and LCA Melo are research fellows of the National Council for Scientific and Technological Development.

\section{Authors' contributions}

Conceptualization: AAL SMOL FMSM LCAM. Experimental design: AAL AASC RAL SMOL FMSM LCAM. Laboratory analysis: AAL AASC RAL SMOL JFLF. Supervision: FMSM LCAM. Data analysis and interpretation: AAL AASC FMSM LCAM. Manuscript drafting: AAL. Manuscript review \& editing: All authors. Manuscript approval: All authors read and approved the final manuscript.

\section{Competing interests}

The authors declare that they have no competing interests.

Received: 30 September 2019 Accepted: 29 January 2020

Published online: 26 February 2020

\section{References}

Abdala DB, da Silva IR, Vergütz L, Sparks DL (2015) Long-term manure application effects on phosphorus speciation, kinetics and distribution in highly weathered agricultural soils. Chemosphere 119:504-514 https://doi.org/10. 1016/j.chemosphere.2014.07.029

Achal V, Savant W, Reddy MS (2007) Phosphate solubilization by a wild type strain and UV-induced mutants of Aspergillus tubingensis. Soil Biol Biochem 39:695-699 https://doi.org/10.1016/j.soilbio.2006.09.003

Alexander M (1961) Introduction to soil microbiology. John Wiley and Sons, New York/London

Ali MA, Dzombak DA (1996) Competitive sorption of simple organic acids and sulfate on goethite. Environ Sci Technol 30:1061-1071 https://doi.org/10. 1021/es940723g

Anderson CR, Condron LM, Clough TJ, Fiers M, Stewart A, Hill RA, Sherlock RR (2011) Biochar induced soil microbial community change: implications for biogeochemical cycling of carbon, nitrogen and phosphorus. Pedobiologia (Jena) 54:309-320 https://doi.org/10.1016/j.pedobi.2011.07.005

Bekiaris G, Peltre C, Jensen LS, Bruun S (2016) Using FTIR-photoacoustic spectroscopy for phosphorus speciation analysis of biochars. Spectrochim Acta Part A Mol Biomol Spectrosc 168:29-36 https://10.1016/j.saa.2016.05.049 
Bera T, Collins HP, Alva AK, Purakayastha TJ, Patra AK (2016) Biochar and manure effluent effects on soil biochemical properties under corn production. Appl Soil Ecol 107:360-367 https://doi.org/10.1016/j.apsoil.2016.07.011

Bolan NS, Naidu R, Mahimairaja S, Baskaran S (1994) Influence of low-molecularweight organic acids on the solubilization of phosphates. Biol Fertil Soils 18 311-319 https://doi.org/10.1007/BF00570634

Bornø ML, Eduah JO, Müller-Stöver DS, Liu F (2018) Effect of different biochars on phosphorus (P) dynamics in the rhizosphere of Zea mays L. (maize). Plant Soil 431:257-272 https://doi.org/10.1007/s11104-018-3762-y

Carneiro JSDS, Lustosa Filho JF, Nardis BO, Soares RJ, Zinn YL, Melo LCA (2018) Carbon stability of engineered biochar-based phosphate fertilizers. ACS Sustain Chem Eng 6:14203-14212. https://doi.org/. https://doi.org/10.1021/ acssuschemeng.8b02841

Chen D, Yu X, Song C, Pang X, Huang J, Li Y (2016a) Effect of pyrolysis temperature on the chemical oxidation stability of bamboo biochar. Bioresour Technol 218 1303-1306 https://doi.org/10.1016/j.biortech.2016.07.112

Chen W, Yang F, Zhang L, Wang J (2016b) Organic acid secretion and phosphate solubilizing efficiency of Pseudomonas sp. PSB12: effects of phosphorus forms and carbon sources. Geomicrobiol J 33:870-877 https://doi.org/10.1080/ 01490451.2015 .1123329

Chen Y, Shinogi Y, Taira M (2010) Influence of biochar use on sugarcane growth, soil parameters, and groundwater quality. Aust J Soil Res 48:526-530 https:// doi.org/10.1071/SR10011

Chen YP, Rekha PD, Arun AB, Shen FT, Lai WA, Young CC (2006) Phosphate solubilizing bacteria from subtropical soil and their tricalcium phosphate solubilizing abilities. Appl Soil Ecol 34:33-41 https://doi.org/10.1016/j.apsoil. 2005.12 .002

Chien SH, Prochnow LI, Tu S, Snyder CS (2011) Agronomic and environmental aspects of phosphate fertilizers varying in source and solubility: an update review. Nutr Cycl Agroecosyst 89:229-255 https://doi.org/10.1007/s10705010-9390-4

da Costa EM, de Carvalho F, Nóbrega RSA, Silva JS, Moreira FMS (2016) Bacterial strains from floodplain soils perform different plant-growth promoting processes and enhance cowpea growth. Sci Agric 73:301-310 https://doi. org/10.1590/0103-9016-2015-0294

da Costa EM, de Lima W, Oliveira-Longatti SM, de Souza FM (2015) Phosphatesolubilising bacteria enhance Oryza sativa growth and nutrient accumulation in an oxisol fertilized with rock phosphate. Ecol Eng 83:380-385 https://doi. org/10.1016/j.ecoleng.2015.06.045

de Oliveira-Longatti SM, Marra LM, Moreira FMDS (2013) Evaluation of plant growth-promoting traits of Burkholderia and Rhizobium strains isolated from Amazon soils for their co-inoculation in common bean. Afr J Microbiol Res 7: 948-959 https://doi.org/10.5897/ajmr12.1055

Deb D, Kloft M, Lässig J, Walsh S (2016) Variable effects of biochar and P solubilizing microbes on crop productivity in different soil conditions. Agroecol Sustain Food Syst 40:145-168 https://doi.org/10.1080/21683565 2015.1118001

Dick CF, Dos-Santos ALA, Meyer-Fernandes JR (2011) Inorganic phosphate as an important regulator of phosphatases. Enzyme Res 2011. https://doi.org/10. 4061/2011/103980

Ding Y, Liu YX, Wu WX, Shi DZ, Yang M, Zhong ZK (2010) Evaluation of biochar effects on nitrogen retention and leaching in multi-layered soil columns. Water Air Soil Pollut 213:47-55 https://doi.org/10.1007/s11270-010-0366-4

Eivazi F, Tabatabai MA (1977) Phosphates in soils. Soil Biol Biochem 9:167-172

El-Naggar A, Lee SS, Rinklebe J et al (2019) Biochar application to low fertility soils: a review of current status, and future prospects. Geoderma 337:536-554 https://10.1016/j.geoderma.2018.09.034

Estrada GA, Baldani VLD, de Oliveira DM, Urquiaga S, Baldani JI (2013) Selection of phosphate-solubilizing diazotrophic Herbaspirillum and Burkholderia strains and their effect on rice crop yield and nutrient uptake. Plant Soil 369:115129 https://doi.org/10.1007/s11104-012-1550-7

Fox A, Gahan J, Ikoyi I, Kwapinski W, O'Sullivan O, Cotter PD, Schmalenberger A (2016) Miscanthus biochar promotes growth of spring barley and shifts bacterial community structures including phosphorus and sulfur mobilizing bacteria. Pedobiologia (Jena) 59:195-202 https://doi.org/10.1016/j.pedobi. 2016.07.003

Gaskin JW, Steiner C, Harris K, Das KC, Bibens B (2008) Effect of low-temperature pyrolysis conditions on biochar for agricultural use. Trans ASABE 51:20612069 https://doi.org/10.13031/2013.25409

Geelhoed JS, Riemsdijk WHVAN, Findenegg GR (1999) Simulation of the effect of citrate exudation from roots on the plant availability of phosphate adsorbed on goethite. Eur J Soil Sci 50:379-390 https://doi.org/10.1046/j.1365-2389. 1999.00251.x

Głodowska M, Husk B, Schwinghamer T, Smith D (2016) Biochar is a growth-promoting alternative to peat moss for the inoculation of corn with a pseudomonad. Agron Sustain Dev 36:1-10 https:/doi.org/10.1007/s13593-016-0356-z

Hamdali H, Bouizgarne B, Hafidi M, Lebrihi A, Virolle MJ, Ouhdouch Y (2008) Screening for rock phosphate solubilizing Actinomycetes from Moroccan phosphate mines. Appl Soil Ecol 38:12-19 https://doi.org/10.1016/j.apsoil. 2007.08.007

Herbien SA, Neal JL (1990) Soil pH and phosphatase activity. Commun Soil Sci Plant Anal 21:439-456 https://doi.org/10.1080/00103629009368244

Illmer P, Schinner F (1992) Solubilization of inorganic phosphates by microorganisms isolated from forest soils. Soil Biol Biochem 24:389-395 https://doi.org/10.1016/0038-0717(92)90199-8

Jacoby R, Peukert M, Succurro A, Koprivova A, Kopriva S (2017) The role of soil microorganisms in plant mineral nutrition - current knowledge and future directions. Front Plant Sci 8:1-19 https://doi.org/10.3389/fpls.2017.01617

Jones DL (1998) Organic acids in the rhizosphere - a critical review. Plant Soil 205:25-44 https://doi.org/10.1023/A:1004356007312

Juma NG, Tabatabai MA (1988) Phosphatase activity in corn and soybean roots: conditions for assay and effects of metals. Plant Soil 107:39-47 https://doi. org/10.1007/BF02371542

Kaur G, Reddy MS (2014) Role of phosphate-solubilizing bacteria in improving the soil fertility and crop productivity in organic farming. Arch Agron Soil Sci 60:549-564 https://doi.org/10.1080/03650340.2013.817667

Khan AA, Jilani G, Akhtar MS, Salqlan SM, Rasheed M (2009) Phosphorus solubilizing bacteria: occurrence, mechanisms and their role in crop production. J Agric Biol Sci 1:48-58

Kpomblekou K, Tabatabai MA (1994) Effect of organic acid on release of phosphorus from phosphate rocks. Soil Sci 158:441-453 https://doi.org/10. 1097/00010694-199415860-00006

Lehmann J, Rillig MC, Thies J, Masiello CA, Hockaday WC, Crowley D (2011) Biochar effects on soil biota - a review. Soil Biol Biochem 43:1812-1836 https://doi.org/10.1016/j.soilbio.2011.04.022

Liu FP, Liu HQ, Zhou HL, Dong ZG, Bai XH, Qiao JJ (2014) Isolation and characterization of phosphate-solubilizing bacteria from betel nut (Areca catechu) and their effects on plant growth and phosphorus mobilization in tropical soils. Biol Fertil Soils 50: 927-937 https:/doi.org/10.1007/s00374-014-0913-z

Lustosa Filho JF, Barbosa CF, Carneiro JS, Da S, Melo LA (2019) Diffusion and phosphorus solubility of biochar-based fertilizer: visualization, chemical assessment and availability to plants. Soil Tillage Res 194:104298 https://doi. org/10.1016/j.still.2019.104298

Lustosa Filho JF, Penido ES, Castro PP, Silva CA, Melo LCA (2017) Co-pyrolysis of poultry litter and phosphate and magnesium generates alternative slowrelease fertilizer suitable for tropical soils. ACS Sustain Chem Eng 5:90439052 https://doi.org/10.1021/acssuschemeng.7b01935

Ma Z, Chen D, Gu J et al (2015) Determination of pyrolysis characteristics and kinetics of palm kernel shell using TGA-FTIR and model-free integral methods. Energy Convers Manag 89:251-259 https://doi.org/10.1016/j. enconman.2014.09.074

Margalef O, Sardans J, Fernández-Martínez M, Molowny-Horas R, Janssens IA, Ciais P, Goll D, Richter A, Obersteiner M, Asensio D, Peñuelas J (2017) Global patterns of phosphatase activity in natural soils. Sci Rep 7:1-13 https://doi. org/10.1038/s41598-017-01418-8

Marra LM, de Oliveira SM, Soares CRFS, Moreira FMS (2011) Solubilisation of inorganic phosphates by inoculant strains from tropical legumes. Sci Agric 68:603-609 https://doi.org/10.1590/s0103-90162011000500015

Marra LM, de Oliveira-Longatti SM, Soares CRFS, Olivares FL, Moreira FMS (2019) The amount of phosphate solubilization depends on the strain, C-source, organic acids and type of phosphate. Geomicrobiol J 36:232-242 https://doi. org/10.1080/01490451.2018.1542469

Marra LM, Sousa Soares CRF, de Oliveira SM, Ferreira PAA, Soares BL, de Carvalho RF, de Lima JM, Moreira FMS (2012) Biological nitrogen fixation and phosphate solubilization by bacteria isolated from tropical soils. Plant Soil 357:289-307 https://doi.org/10.1007/s11104-012-1157-z

Nautiyal CS (1999) An efficient microbiological growth medium for screening phosphate solubilizing microorganisms. FEMS Microbiol Lett 170:265-270

Nguyen TTN, Xu CY, Tahmasbian I, Che R, Xu Z, Zhou X, Wallace HM, Bai SH (2017) Effects of biochar on soil available inorganic nitrogen: a review and meta-analysis. Geoderma 288:79-96 https://doi.org/10.1016/ j.geoderma.2016.11.004 
Nigussie A, Kissi E, Misganaw M, Ambaw G (2012) Effect of biochar application on soil properties and nutrient uptake of lettuces (Lactuca sativa) grown in chromium polluted soils. Environ Sci 12:369376

Park JH, Bolan N, Megharaj M, Naidu R (2011) Isolation of phosphate solubilizing bacteria and their potential for lead immobilization in soil. J Hazard Mater 185:829-836 https://doi.org/10.1016/j.jhazmat.2010.09.095

Pereira SIA, Castro PML (2014) Phosphate-solubilizing rhizobacteria enhance Zea mays growth in agricultural P-deficient soils. Ecol Eng 73:526-535 https://doi. org/10.1016/j.ecoleng.2014.09.060

Puga AP, Abreu CA, Melo LCA, Beesley L (2015) Biochar application to a contaminated soil reduces the availability and plant uptake of zinc, lead and cadmium. J Environ Manag 159:86-93 https://doi.org/10.1016/j.jenvman.2015.05.036

Rafique M, Sultan T, Ortas I, Chaudhary HJ (2017) Enhancement of maize plant growth with inoculation of phosphate-solubilizing bacteria and biochar amendment in soil. Soil Sci Plant Nutr 63:460-469 https://doi.org/10.1080/ 00380768.2017.1373599

Rajkovich S, Enders A, Hanley K, Hyland C, Zimmerman AR, Lehmann J (2012) Corn growth and nitrogen nutrition after additions of biochars with varying properties to a temperate soil. Biol Fertil Soils 48:271-284 https://doi.org/10. 1007/s00374-011-0624-7

Richardson AE (2002) Prospects for using soil microorganisms to improve the acquisition of phosphorus by plants. Funct Plant Biol 28:897 https://doi.org/ 10.1071/pp01093

Richardson AE, Barea JM, McNeill AM, Prigent-Combaret C (2009) Acquisition of phosphorus and nitrogen in the rhizosphere and plant growth promotion by microorganisms. Plant Soil 321:305-339 https://doi.org/10.1007/s11104-0099895-2

Rodríguez H, Fraga R (1999) Phosphate solubilizing bacteria and their role in plant growth promotion. Biotechnol Adv 17:319-339 https://doi.org/10.1016/ S0734-9750(99)00014-2

Saxena J, Rana G, Pandey M (2013) Impact of addition of biochar along with Bacillus sp. on growth and yield of French beans. Sci Hortic (Amsterdam) 162:351-356 https://doi.org/10.1016/j.scienta.2013.08.002

Scholz RW, Ulrich AE, Eilittä M, Roy A (2013) Sustainable use of phosphorus: a finite resource. Sci Total Environ 461-462:799-803 https://doi.org/10.1016/j. scitotenv.2013.05.043

Sharma SB, Sayyed RZ, Trivedi MH, Gobi TA (2013) Phosphate solubilizing microbes: sustainable approach for managing phosphorus deficiency in agricultural soils. Springerplus 2:1-14 https://doi.org/10.1186/2193-1801-2-587

Silva K, Cassetari AS, Lima AS, De Brandt E, Pinnock E, Vandamme P, Moreira FMS (2012) Diazotrophic Burkholderia species isolated from the Amazon region exhibit phenotypical, functional and genetic diversity. Syst Appl Microbiol 35 253-262 https://doi.org/10.1016/j.syapm.2012.04.001

Singh BP, Cowie AL, Smernik RJ (2012) Biochar carbon stability in a clayey soil as a function of feedstock and pyrolysis temperature. Environ Sci Technol 46: 11770-11778 https://doi.org/10.1021/es302545b

Strom L, Owen AG, Godbold DL, Jones DL (2001) Organic acid behaviour in a calcareous soil: sorption reactions and biodegradation rates. Soil Biol Biochem 33:2125-2133 https://doi.org/10.1016/S0038-0717(01)00146-8

Tao GC, Tian SJ, Cai MY, Xie GH (2008) Phosphate-solubilizing and -mineralizing abilities of bacteria isolated from soils. Pedosphere 18:515-523 https://doi. org/10.1016/s1002-0160(08)60042-9

Vanek SJ, Lehmann J (2015) Phosphorus availability to beans via interactions between mycorrhizas and biochar. Plant Soil 395:105-123 https://doi.org/10. 1007/s11104-014-2246-y

Wang Y, Lin Y, Chiu PC, Imhoff PT, Guo M (2015) Phosphorus release behaviors of poultry litter biochar as a soil amendment. Sci Total Environ 512-513:454463 https://doi.org/10.1016/j.scitotenv.2015.01.093

Warnock DD, Lehmann J, Kuyper TW, Rillig MC (2007) Mycorrhizal responses to biochar in soil - concepts and mechanisms. Plant Soil 300:9-20 https://doi. org/10.1007/s11104-007-9391-5

Wei Y, Zhao Y, Wang H et al (2016) An optimized regulating method for composting phosphorus fractions transformation based on biochar addition and phosphate-solubilizing bacteria inoculation. Bioresour Technol 221:139146 https://doi.org/10.1016/j.biortech.2016.09.038

Yi Y, Huang W, Ge Y (2008) Exopolysaccharide: a novel important factor in the microbial dissolution of tricalcium phosphate. World J Microbiol Biotechnol 24:1059-1065 https://doi.org/10.1007/s11274-007-9575-4

Yu X, Liu X, Zhu TH, Liu GH, Mao C (2011) Isolation and characterization of phosphatesolubilizing bacteria from walnut and their effect on growth and phosphorus mobilization. Biol Fertil Soils 47:437-446 https:/doi.org/10.1007/s00374-011-0548-2
Yu X, Liu X, Zhu TH, Liu GH, Mao C (2012) Co-inoculation with phosphatesolubilzing and nitrogen-fixing bacteria on solubilization of rock phosphate and their effect on growth promotion and nutrient uptake by walnut. Eur Soil Biol 50:112-117 https://doi.org/10.1016/j.ejsobi.2012.01.004

Zhang L, Jing Y, Xiang Y, Zhang R, Lu H (2018) Responses of soil microbial community structure changes and activities to biochar addition: a meta-analysis. Sci Total Environ 643:926-935 https://doi.org/10.1016/j.scitotenv.2018.06.231

Zhao L, Cao X, Zheng W, Kan Y (2014) Phosphorus-assisted biomass thermal conversion: reducing carbon loss and improving biochar stability. PLoS One 9:1-15 https://doi.org/10.1371/journal.pone.0115373

Zhao L, Cao X, Zheng W, Scott JW, Sharma BK, Chen X (2016) Copyrolysis of biomass with phosphate fertilizers to improve biochar carbon retention, slow nutrient release, and stabilize heavy metals in soil. ACS Sustain Chem Eng 4: 1630-1636 https://doi.org/10.1021/acssuschemeng.5b01570

Zhao R, Jiang D, Coles N, Wu J (2015) Effects of biochar on the acidity of a loamy clay soil under different incubation conditions. J Soils Sediments 15:19191926 https://doi.org/10.1007/s11368-015-1143-1

\section{Publisher's Note}

Springer Nature remains neutral with regard to jurisdictional claims in published maps and institutional affiliations.

\section{Ready to submit your research? Choose BMC and benefit from:}

- fast, convenient online submission

- thorough peer review by experienced researchers in your field

- rapid publication on acceptance

- support for research data, including large and complex data types

- gold Open Access which fosters wider collaboration and increased citations

- maximum visibility for your research: over $100 \mathrm{M}$ website views per year

At BMC, research is always in progress.

Learn more biomedcentral.com/submissions 